\title{
Aleksandra Brzemia-Bonarek
}

\section{Prawda w świetle znowelizowanego kodeksu postępowania cywilnego}

Prawo Kanoniczne : kwartalnik prawno-historyczny 51/3-4, 385-397

2008

Artykuł został opracowany do udostępnienia w internecie przez Muzeum Historii Polski w ramach prac podejmowanych na rzecz zapewnienia otwartego, powszechnego i trwałego dostępu do polskiego dorobku naukowego i kulturalnego. Artykuł jest umieszczony w kolekcji cyfrowej bazhum.muzhp.pl, gromadzącej zawartość polskich czasopism humanistycznych i społecznych.

Tekst jest udostępniony do wykorzystania w ramach dozwolonego użytku. 


\section{PRAWDA W ŚWIETLE ZNOWELIZOWANEGO KODEKSU POSTĘPOWANIA CYWILNEGO.}

Treść: Wstęp. - 1. Przestawienie zagadnienia. - 2. Argumenty doktryny i praktyków. - 3. Meandry prawdy w obowiązującym procesie cywilnym. 4. Prawda jako podstawowa wartość $\mathrm{w}$ procesie.

\section{Wstęp}

Niniejszy artykuł jest krótkim przeglądem ukazującym przeobrażenie jakim uległa zasada prawdy materialnej w procesie cywilnym pod wpływem nowelizacji kodeksu postępowania cywilnego rozpoczętej w 1996 r. Autorka przyznaje, że podstawowe cele ustawodawcy leżące u podstaw reform były słuszne, jednak krytycznie wypowiada się na temat tendencji do minimalizacji prawdy obiektywnej i wzrostu przejawów prawdy formalnej.

Publikacja ta powstała w ramach projektu badawczego dotyczącego problematyki prawdy w kanonicznym procesie małżeńskim, przyznanego na lata 2008-2010 przez Ministerstwo Nauki ${ }^{1}$.

\section{Przedstawienie zagadnienia}

Na przestrzeni ostatnich 12 lat w zostały uchwalone przez Sejm ustawy, które zmieniły obraz polskiego postępowania cywilnego z 17 listopada 1964 r. $^{2}$ Proces nowelizacji kodeksu rozpoczą się w marcu 1996 i objął wszystkie jego części. Gruntowne reformy

\footnotetext{
${ }^{1}$ Koncepcja prawdy orzekanej w kanonicznym procesie matżeńskim, grant nr: NN 110 2727324.

${ }^{2}$ Dz. U. Nr 43, poz. 296. z późn. zmianami.
} 
w zasadzie zakończyły się w 2004 roku, choć zmiany nie stanowiące już całkowitego novum ustawodawca uchwalał także później. ${ }^{3}$

Decyzja legislatora spowodowana była potrzebą dostosowania polskiego prawa do wymogów unijnych procedur cywilnych, pełnej realizacji konstytucyjnych zasad równości stron $\mathrm{w}$ procesie i prawa do szybkiego rozpatrzenia przez sąd sprawy.

Bodajże najbardziej rewolucyjną, wzbudzającą liczne polemik i dyskusje w środowisku prawniczym zmianą było uchylenie paragrafu drugiego art. 3 k.p.c.: sad powinien dązyć do wszechstronnego zbadania wszystkich okoliczności sprawy $i$ do wyjaśnienia rzeczywistej treści stosunków faktycznych i prawnych. Przepis ten formułował ogólnie zasadę prymatu prawdy w procesie cywilnym. Skreślenie przytoczonego przepisu nastąiło na samym początku procesu nowelizacji ${ }^{4}$ a eliminacja pozostałych norm będących wyrazem tej zasady była konsekwentnie kontynuowana w miarę zmieniania kolejnych części kodeksus.

Aktualnie obowiązujący przepis art. 3 k.p.c. składa się z jednego zdania i brzmi następująco: strony $i$ uczestnicy postępowania obowiązani sa dawać wyjaśnienia co do okoliczności sprawy zgodnie z prawda i bez zatajania czegokolwiek oraz przedstawić dowody. $\mathrm{W}$ połączeniu $\mathrm{z}$ art. 6 kodeksu stanowiącym, iż ciężar dowodzenia spoczywa na osobie, która $z$ tego faktu wywodzi skutki prawne, ustawa z 1996 r. o zmianie kodeksu postępowania cywilnego wyznaczyła nowy standard postępowania stron i sądu w procesie cywilnym oraz poważnie wzmocniła zasadę sporności. To właśnie kontradyktoryjność i równość stron w procesie wysuwane są obecnie jako najważniejsze kodeksowe zasady postępowania w dzisiejszej sytuacji społeczno-gospodarczej, zaś obowiązek wykrycia przez sąd prawdy stał się de facto postulatem ${ }^{6}$.

\footnotetext{
${ }^{3}$ Ostatnia poprawka w chwili pisania niniejszego artykułu pochodzi z 9 maja $2007 \mathrm{r}$., Dz. U., Nr 121, poz. 831.

${ }^{4}$ Ustawa z 1 marca 1996 r. o zmianie Kodeksu postępowania cywilnego, rozporządzeń Prezydenta Rzeczpospolitej - Prawo upadłościowe i Prawo o postępowaniu układowym, Kodeksu postępowania administracyjnego, Ustawy o kosztach sądowych w sprawach cywilnych oraz niektórych innych ustaw (Dz. U.1996, Nr 43, poz. 189).

${ }^{5}$ Por. S. D a $1 \mathrm{k}$ a, M. K o e n n e r, Nowelizacja KPC z 2.7.2004r. z komentarzem - cz I. Edukacja Prawnicza 2004, nr 10, s. 21-34. Autorzy w obrazowy sposób i z krótkim komentarzem przedstawili zmiany w poszczególnych przepisach.

${ }^{6}$ T. P i e tr z y k ow s ki, B. W o j c i e c h ow s k i, Równość, prawda i sprawiedliwość w procesie cywilnym. Rozważania na tle nowelizacji k.p.c., Palestra 2004, nr 9-10, s.
} 


\section{Argumenty doktryny i praktyków}

W literaturze przedmiotu, wśród autorów opowiadających się z uznaniem o zmianie art. 3 k.p.c. można wyodrębnić kilka przenikających się powodów, dla których rezygnacja z prymatu prawdy miała być słuszna.

1. Najczęściej podnoszonym argumentem były negatywne doświadczenia związane $\mathrm{z}$ niską efektywnością pracy sądów. Sąd zobowiązany $\mathrm{z}$ urzędu do wszechstronnego zbadania wszystkich okoliczności sprawy prowadził sprawę długo i mało skutecznie, nierzadko przy bierności stron. Wytworzyła się praktyka, w której nie tylko strony, ale również profesjonalni pełnomocnicy nie wskazywali sądowi środków dowodowych ani nie wnioskowali o możliwość ich zdobycia, lecz „przerzucali” ciężar inicjatywy dowodowej na sądy. W razie zaś orzeczenia niezgodnego z ich odczuciem sprawiedliwości zarzut „,niewyjaśniania przez sąd wszystkich okoliczności sprawy" mógł zostać wykorzystany w procesie odwoławczym. Takie działanie paraliżowało pracę sądów, co przedstawili na postawie własnych badań empirycznych już w latach $80 \mathrm{XX}$ wieku sędziowie G. Bieniek i E. Warzocha ${ }^{7}$. Współcześni procesualiści cywilni bardzo silnie podkreślali te negatywne dla praworządności skutki, zwracając uwagę, że zarzucana Polsce przez Europejski Trybunał Praw Człowieka przewlekłość postępowania była spowodowana właśnie obowiązkiem działania przez sąd z urzędu w postępowaniu cywilnym ${ }^{8}$.

2. Zobowiązanie sądu do wykrycia w procesie prawdy obiektywnej łączyło się z działaniami sądu o charakterze inkwizycyjnym, co było sprzeczne $\mathrm{z}$ duchem kontradyktoryjności i równości stron. Charakter śledczy postępowania ma swoje pełne uzasadnienie w pro-

15; Kontradyktoryjność przed prawdą omawia w swoim komentarzu do k.p.c. Marcin Uliasz. Zob. M. U l i a s z, Kodeks postepowania cywilnego. Tom I. Komentarz do artykutów 1-505 ${ }^{14}$. Warszawa 2007, s. 140; J. D o m i n o w s k a, Nowelizacja kodeksu postępowania cywilnego - zmiany wprowadzone w postępowaniu rozpoznawczym ustawa z dnia 2 lipca 2004 r., Przegląd Sądowy 2005, nr 4, s. 25.

${ }^{7} \mathrm{G}$. B i e $\mathrm{n}$ i e k, E. W a r z o c h a, Funkcjonowanie przepisów kodeksu postępowania cywilnego w praktyce sądów powszechnych, Nowe Prawo $1985 \mathrm{nr} 3$, s. 3 i nast.

${ }^{8}$ Obowiązek dziatania sądu z urzędu zawsze prowadzit do opóźnienia w pracy sądów i utrudniat możliwość sprawnego i szybkiego zakończenia procesu. Tak np. T. E r e c i ń s k i we Wprowadzeniu do kodeksu postępowania cywilnego. Kodeks postępowania cywilnego. Edycja sadowa, Warszawa 2005, s. 303. Por. także A. J a k u b e c k i, Kontradyktoryjność a poznanie prawdy w k.p.c., Przegląd Sądowy 1998, nr 10, s. 66-67. 
cesie karnym, gdzie funkcją podejmowanych przez sąd czynności jest ochrona porządku publicznego w państwie, a sankcje oznaczają ograniczenie lub pozbawienie wolności osoby skazanej. W procesie cywilnym natomiast spór toczy się o prawa, którymi równe strony procesu mogą swobodnie dysponować ${ }^{9}$ - a więc zarówno bronić ich, jak i z tej obrony zrezygnować. Kontradyktoryjność - zwracali uwage znawcy przedmiotu - także jest metodą wykrycia prawdy: strony zobowiazzane do przytoczenia okoliczności faktycznych uzasadniających ich żądania oraz rzeczywiście równie traktowane przez arbitra, wykazują maksimum staranności i chęci w udowodnieniu przed sądem swoich racji. Tym samym sędzia otrzyma materiał procesowy rzeczywiście wystarczający do ferowania sprawiedliwego wyroku. W literaturze zwracano również uwagę, że usunięcie drugiego zdania art. 3 k.p.c. wyeliminowało istniejącą sprzeczność, jaka istniała pomiędzy rzeczonym nakazem przeprowadzenia przez sąd dowodu z urzędu (por. dawne brzmienie art. 232 k.p.c. „sąd powinien") a zasadą ei incumbit probatio qui dicit, non ei qui negat, wyrażoną w art. 6 tego kodeksu ${ }^{10}$.

Zawężenie kręgu sytuacji, w których sędzia ma działać z urzędu do szczególnych przypadków (ujawniona bezradność stron, trudne do przezwyciężenia przeszkody w zdobyciu dowodów) ${ }^{11}$, a tym samym zwiększenie zasady kontradyktoryjności spotkało się z uznaniem ludzi nauki oraz praktyków i to niezależnie od wykonywanego zawodu prawniczego. Sędziowie podkreślali, iż większa sporność przyśpieszy ich pracę, a zatem skróci się czas trwania procesu; co w sprawach majątkowych i gospodarczych będzie oznaczać mniejsze straty materialne (szybsze otrzymanie odszkodowania, niezachwianie się płynności finansowej przedsiębiorstwa itd.). Potrzeba zaś aktywnego uczestnictwa w swojej sprawie zachęci obywateli do korzystania z profesjonalnej pomocy prawnej, jak wskazywali w swoich publikacjach radcowie prawni i adwokaci. ${ }^{12}$

Badania prawnoporównawcze dowiodły że zasada kontradyk-

${ }^{9}$ J. L a p i e r r e, s. 109 [w:] J. Jo d łow s k i, Z. R e s i c h, J. L a p i e r r e, T. M i s i u k-J o d ł o w s k a, Postępowanie cywilne, Warszawa 1996.

${ }^{10}$ W. J a k u b o w s k i, Kilka uwag o zmianach w k.p.c. Palestra 1996, nr 2, s. 53.

${ }^{11}$ Por. Uchwała 7 sędziów SN z 19 maja 2000r. III CZP 4/00, OSNC 2000 nr 11, poz. 195; w uzasadnieniu.

${ }^{12}$ T. P i e t r z y k o w s ki, B. W o j c i e c h ow s ki, Równość, prawda i sprawiedliwość... op. cit., s. 21-22. 
toryjności jest najsilniej zaznaczana w procedurach anglosaskich, a właśnie w społeczeństwach common law istnieje wysoka kultura prawna i szacunek dla wymiaru sprawiedliwości ${ }^{13}$. Zwolennicy zmian predysponują więc, że długofalową konsekwencją tych zmian będzie wzrost kultury prawnej w Polsce.

3. Z zarzutem braku rzeczywistej kontradyktoryjności łączyły się także wspomniane już negatywne tendencje stron do bierności a niektórych pełnomocników do braku rzetelności zawodowej. Innymi słowy - „opiekuńczy sąd” osłabiał morale stron i nie aktywował je do pełnego i świadomego uczestnictwa w procesie. Zwolennicy „nowoczesnej” ${ }^{14}$ kontradyktoryjności, podkreślają, iż zadaniem sądu jest pobudzać strony do czynnego uczestnictwa w ochronie swoich praw i interesów, a nie dążyć do wyrównywania istniejących między nimi różnic społecznych. W procesie cywilnym w większości przypadków spór dotyczy prywatnych praw osób fizycznych bądź prawnych. Może jednak może dojść do sytuacji, gdy zarówno powód jak i pozwany skutecznie ukryją przed sądem jakiś fakt czy okoliczność istotną dla zgodnego z prawdą osądzenia. Przed nowelizacją z 1996 r. sąd de facto brał odpowiedzialności za rezultat postępowania dowodowego, choć obowiązująca już wówczas zasada rozporządzalności stanowiła iż dysponentem tej części procesu były strony. ${ }^{15}$ Obecnie, strony procesu nie mogą w postępowaniu apelacyjnym zarzucić sądowi, iż ten niepodejmując $\mathrm{w}$ postępowaniu dowodowym działań z urzędu niedokładnie prowadził sprawę.

4. Opiekuńcza rola sądu powodowała w doktrynie duże wątpliwości co do właściwego funkcjonowania w polskich sądach zasad: bezstronności sądu i równości stron, tak mocno podkreślanych w orzecznictwie Europejskiego Trybunału Praw Człowieka. Sędzia - zmuszony do uzupełnienia dowodów raz powoda a raz pozwanego, nie był - przynajmniej w oczach strony, w tym czasie nie będącej pod „opieką" sądu - bezstronnym, neutralnym arbitrem. Obo-

${ }^{13}$ Por. Z. Res i ch, J. L a pierre, s. 22 [w:] J. Jo dłow s k i, Z. R e s i ch, J. L a p i e r r e, T. M i s i u k-Jo dło w s k a, Postepowanie cywilne.. op. cit.; T. P i e t r z y k ow s k i, B. W o j c i e c h o w s k i, Równość, prawda i sprawiedliwość... op. cit., s. 11. $\mathrm{s} \mathrm{k} \mathrm{a.}$

${ }^{14}$ Cytowani w tej publikacji: T. E r e c iń s k i, A. J a k u b o w s k i, J. D o m i n o w -

${ }^{15}$ Szerzej na ten temat: T. E r e c iń s k i, O nowelizacji kodeksu postępowania cywilnego w ogólności, Przegląd Sądowy 1996, nr 10, s. 4-5; H. P i e t r z k o w s k i, Zarys metodyki pracy sędziego, Warszawa 2007 (wyd. 3) s. 26-27. 
wiązek działania sądu z urzędu pod rządami dawnego k.p.c. - a co za tym idzie urzeczywistnianie elementów śledczych - był nieproporcjonalnie wielki $\mathrm{w}$ stosunku zasady kontradyktoryjności i równości stron. Takie działanie sądu zaburzało właściwe relacje wzajemnego oddziaływania na siebie innych zasad procesowych. Za wyjątkiem sytuacji, gdy w grę wchodzi pierwiastek publicznoprawny (np. w sprawach z zakresu prawa rodzinnego i opiekuńczego, sprawach o alimenty, w mniejszym stopniu w sporach z zakresu prawa pracy) - sąd nie powinien ingerować w proces dowodzenia inaczej, niż poprzez wszechstronne aktywowanie stron do przedkładania swoich racji i do prawdomówności ${ }^{16}$.

5. Wśród argumentów przemawiających za potrzebą rezygnacji z zasady prawdy obiektywnej we spółczesnym postępowaniu cywilnym był również i taki, że teoria prymatu prawdy obiektywnej to pozostałość socjalistycznej koncepcji procesu. W przedwojennym kodeksie postępowania cywilnego z 1932 roku królowała zasada prawdy formalnej ${ }^{17}$. Samo sformułowanie „prawda obiektywna” zostało wykreowane przez marksistowską teorię prawa, wprowadzone początkowo do radzieckiego kodeksu postępowania cywilnego w latach trzydziestych, a następnie, po II wojnie światowej sukcesywnie wpisywane do analogicznych kodeksów państw satelitarnych. W Polsce nazwa: „zasada prawdy obiektywnej” została przyjęta 27 maja 1953 roku poprzez uchwałe całej Izby Cywilnej Sądu Najwyższego ${ }^{18}$. W odróżnieniu od zachodnioeuropejskiej prawdy „materialnej”, prawda „obiektywna” była nacechowana ideologią walki klas, socjalistycznie rozumianą sprawiedliwością społeczną, ochroną tzw. jednostek słabszych, do których należały przede wszystkim „klasy pracujące”, oraz opiekuńczością sądu, który najlepiej wiedział, co dla stron jest dobre i słuszne, stąd wzrost elementów inkwizycyjnych.

Realizacja zasady obiektywnej przez sądy miała urzeczywistniać się właśnie $\mathrm{w}$ angażowaniu $\mathrm{w}$ sprawę niemal na równi ze strona-

${ }^{16}$ Por. A. J a k u b e c k i, Kontradyktoryjność a poznanie prawdy w k.p.c., Przegląd Sądowy 1998, nr 10, s. 66-71, T. E r e c i ń s k i, Wprowadzenie..., op. cit., 303; T. P i e t r z k o w s k i, Zarys metodyki..., op. cit., s. 28.

${ }^{17}$ A. J a k u b e c k i, Kontradyktoryjność... op. cit., s. 74. W artykule podana również literatura przedmiotu oraz analiza porównawcza niektórych przepisów k.p.c. z 1932 roku, nowelizacji z lat 50 i $60 \mathrm{XX}$ wieku oraz obowiązujących reguł.

${ }^{18}$ C. Prez. 195/52, OSNCP 1953 nr 4, poz. 95. 
mi (a nawet przy ich braku zainteresowania) poprzez gromadzenie materiału dowodnego ex officio i odpowiedzialność przez sądem II instancji za rezultat tych czynności. Ustawodawca więc narzucił na sądy nie tylko herkulesowe, lecz wręcz niewykonalne zadanie $^{19}$. Argument „uwolnienia się od idei socjalistycznego procesu cywilnego" jako konsekwencja przekonwertowania zasady prawdy w procesie był podnoszony przez wszystkich zwolenników zmiany art. 3 k.p.c. ${ }^{20}$ powoływanych w niniejszym artykule.

Prawnicy zgłębiający to zagadnienie krytykowali również samo istnienie zasadności wyrażenia „prawda obiektywna”, tłumacząc, że omawianemu związkowi frazeologicznemu brak jest logiki: suponuje on jakoby istniała jakaś inna prawda w dodatku „nieobiektywna”21.

\section{Meandry prawdy w obowiązującym procesie cywilnym.}

W publikacjach przeznaczonych dla studentów i aplikantów podział zasad procesowych przebiega tradycyjnie: zasada prawdy jest wymieniana jako naczelna zasada procesu cywilnego, choć zwraca się uwagę, że uwidacznia się ona przede wszystkim w obowiązku przedstawiania prawdziwych okoliczności o sprawie przez strony. Naruszenia tego obowiązku nie można natomiast zarzucić sądowi. W podręcznikach, skryptach i komentarzach podkreśla się, iż urzeczywistnianiu się tej zasady służą inne naczelne zasady postępowania cywilnego, przede wszystkim zasada kontradyktoryjności i równości stron. Dochodzenie prawdy w procesie przez sądy powinno urzeczywistniać się (ale również i ograniczać) przez: dopuszczenie dowodów zgłoszonych przez strony (wyjątkowo z urzędu) przeprowadzenie ich i ocenianie. Wszelkie inne przepisy kodeksu, np. obowiązek zadawania pytań i dążenia do wyjaśnienia innych

\footnotetext{
${ }^{19}$ H. P i e t r z k o w s k i, Zarys metodyki... op. cit., s. 25.

${ }^{20}$ Wśród cytowanej literatury najwięcej w: A. J a k u b e c k i, Kontradyktoryjność... op. cit., s. 64-66 i nast.; A. Z i e li ń s k i, Kodeks postępowania cywilnego po nowelizacji w 1996 r., Palestra, 1996 nr. 3-4, s. 13; H. P i e t r z k o w s k i, Zarys metodyki... op. cit., s. 25, Kodeks postępowania cywilnego. Komentarz, tom I. część pierwsza Postępowanie rozpoznawcze, red. T. E r e c i ń s k i, Warszawa 2007(2 wyd.), art. 3.

${ }^{21}$ J. J o dło ow s k i, J. L a p i e r r e, przypis 35, s. 125, [w:] Postępowanie cywilne, J o dłow s ki, Z. Re s i c h, J. L a p i e r r e, T. M is i u k-Jo dłow s k a, Warszawa 2000.
} 
istotnych okoliczności sprawy - art. 212 k.p.c. - są uprawnieniem sądu, a nie jego obowiązkiem ${ }^{22}$.

Niewielu badaczy uważa, że wraz ze zmianą kodeksu postępowania cywilnego wprowadzono prymat prawdy formalnej nad materialnąa ${ }^{23}$. Większość autorów zgadza się z twierdzeniem, iż usunięcie drugiego człony art. 3 k.p.c. było decyzją rewolucyjną w spojrzeniu na zagadnienie dojścia sądu do prawdy w procesie, lecz tłumaczy równocześnie, że zmiany te nie spowodowały rezygnacji z zasady prawdy. W ujęciu zwolenników noweli z 1996r. ustawa wprowadziła jedynie inny niż obowiązujący poprzednio sposób dochodzenia do prawdy. ${ }^{24}$ „Nowa” zasada prawdy nie wymaga aktywności sądu w materii wyjaśniania okoliczności sprawy zgodnie z rzeczywistym stanem rzeczy i przedstawiania dowodów za strony. Tym samym, zasada odkrycia prawdy w procesie przez sąd stała się zasadą obowiązku mówienia prawdy przez strony. Rolą sądu ma być natomiast czuwanie nad przestrzeganiem przez uczestników procesu ich procesowej powinności mówienia prawdy ${ }^{25}$.

Jakkolwiek by jednak nie spojrzeć na zagadnienie, nie ulega wątpliwości, że obecnie w całym k.p.c. wcześniejszy wyjątek ograniczenia poznania prawdy stał się normą i nawet przychylni zmianom autorzy przyznają, że nowelizacja zmniejszyła faktyczne możliwości odkrycia prawdy ${ }^{26}$. Analizowano również na ile w co-

${ }^{22} \mathrm{~J}$. J o d ł o w s k i, J. L a p i e r r e, Zasada prawdy materialnej i zakres jej funkcjonowania $w$ polskim procesie cywilnym., s. 108-112 [w:] J o d ł o w s k i, Z. R e s i c h, J. L a p i e r r e, T. M i s i u k-J o dł o w s k a, Postępowanie cywilne, op. cit. (wyd. z 1996 r.); M. U 1 i a s z, Kodeks ...op. cit., s. 141; S. D a 1 k a, M. K o e n e r, Nowelizacja KPC z 2 lipca 2004, Edukacja Prawnicza 2004, nr 10, s. 22.

${ }^{23} \mathrm{~S}$. D a $1 \mathrm{k}$ a, Zmiany $w$ procedurze cywilnej wedtug nowelizacji z 1 marca 1996 r., Państwo i Prawo 1996, nr 7-8, s. 29; S. D a 1 k a, M. K o e n e r, Nowelizacja KPC z 2 lipca 2004, Edukacja Prawnicza 2004, nr.10, s. 22.: Od dużej nowelizacji KPC z 1996r., polski ustawodawca konsekwentnie eliminuje unormowania będące wyrazem zasady prawdy obiektywnej. O ile jednak dotychczasowe nie przesądzały o uznaniu za obowiąująca zasadę prawdy formalnej, wydaje się, że obecnie [tj. po zmianach z 2004 r.] nie można mieć w tej kwestii żadnych wattpliwości.

${ }^{24} \mathrm{~A}$. $\mathrm{L}$ a z a r s k a, O prawdzie jako granicy wolności rozporządzania przez strony faktami w procesie cywilnym, Przegląd Sądowy 2008, nr 4, s.146.

${ }^{25}$ Tak stwierdza przedstawicielka młodego pokolenia sędziów, Aneta $Ł$ a z a r s k a, SSR w Warszawie, w cytowanym artykule O prawdzie jako granicy wolności rozporządzania przez strony faktami w procesie cywilnym.

${ }^{26}$ Obecnie, wobec nowelizacji nasuwa się jednak watpliwość, czy poznanie prawdy jest nadal celem polskiego procesu cywilnego. A. J a k u b e c k i, Kontradyktoryjność... op. cit., s. 71. 
dziennej praktyce daje się w ogóle pogodzić rolę wymiaru sprawiedliwości jako efektywnego i sprawnego regulatora stosunków społecznych z wymogiem sprawiedliwego rozwiązywania konfliktów międzyludzkich ${ }^{27}$.

W efekcie tych rozważań cytowani już w tej pracy procesualiści Tomasz Pietrzykowski i Bartosz Wojciechowski przyznali, iż może się zdarzyć, że z uwagi na konieczność szybkiego rozpoznania sprawy, sąd ograniczając swoja aktywność w pouczaniu stron o przystugujacych im prawach, (...) ograniczy tym samym możliwość wnikliwego $i$ wszechstronnego rozpoznania wszystkich okoliczności sprawy ${ }^{28}$.

Co wówczas?

Bardzo stanowczo odpowiada na to pytanie Joanna Dominowska na łamach „Przeglądu Sądowego”. Autorka stoi na stanowisku, iż żaden interes publiczny, z pewnymi wyjątkami, nie ucierpi, zwtaszcza w zakresie postępowania nieprocesowego, jeśli prawda nie zostanie ujawniona.(...) Sąd powinien nadal dażyć do wykrycia prawdy obiektywnej ale nie kosztem naruszenia zasady kontradyktoryjności i dyspozycyjności procesu, które jeśli będa przestrzegane i tak doprowadza do wykrycia prawdy. ${ }^{29}$

Podobnie wypowiada się Tadeusz Ereciński, który nie negując istnienia zasady prawdy uważa, iż sąd nie ma obowiązku dodatkowo dociekać rzeczywistego stanu rzeczy, gdyż zakładałoby to poznawalność tej rzeczywistości w każdym wypadku. Jest rzecza oczywista - pisze Autor w 2005 r. we wprowadzeniu do sądowej edycji kodeksu - że niemożliwe jest ustanowienie gwarancji procesowych, które zawsze zapewniatyby dojście do prawdy: można tylko mówić o wyższym lub niższym stopniu prawdopodobieństwa, więc przywrócenie właściwej roli zasadzie sporności jest najlepsza gwarancją. ${ }^{30}$

${ }^{27}$ T. P i e t r z y k ow s k i, B. W o j c i e c h ow s k i, Równość, prawda i sprawiedliwość... op. cit., s. 23. Rozwiązanie tego napięcia Autorzy artykułu widzą w zwiększeniu dyskrecjonalnej władzy sędziego.

${ }^{28}$ T. P i e tr z y k ow s k i, B. W o j c i e c h ow s ki, Równość, prawda i sprawiedliwość... op. cit., s. 23.

${ }^{29} \mathrm{~J}$. D o m i n o w s k a, Nowelizacja kodeksu postępowania cywilnego-zmiany wprowadzone w postępowaniu rozpoznawczym z dnia 2 lipca 2004r., Przegląd Sądowy, 2005, nr 4, s. 27. W innym miejscu (s. 29): Po spetnieniu przestanek formalnych, takich jak przeprowadzenie dowodów i udzielenie głosu stronom, przewodniczacy po prostu zamyka rozprawę i nie ma obowiązku dążenia, kosztem przedtużania procesu, do petnego wyjaśnienia sprawy.

${ }^{30}$ T. E r e c i ń s k i, Wprowadzenie do Kodeksu postępowanie cywilnego, op. cit., s. 302. 
Także Henryk Pietrzkowski w Metodologii pracy sędziego wskazuje, iż współczesny sprawiedliwy proces postępowania cywilnego nie polega na dojściu do prawdy w każdej sytuacji procesowej $\mathrm{i}$ w każdej sprawie. Wydanie zgodnego z prawda orzeczenia przez sad jest dalej zadaniem sądu, lecz nie oznacza, że w praktyce dojście do tej prawdy nastapi lub musi nastapic ${ }^{31}$.

Nie budzą wątpliwości, ani nie są sprzeczne z poczuciem sprawiedliwości istniejące $\mathrm{w}$ procesie cywilnym ograniczenia w dojściu do prawdy w sprawach o prawa stanu, sprawach małżeńskich, stosunków między rodzicami a dziećmi, gdyż w tych sytuacjach kierowanie się wyłącznie dojściem do prawdy o materii sporu może być sprzeczne z koniecznością ochrony dziecka, godności osobistej, czy zasad współżycia społecznego ${ }^{32}$. Zwolennicy ograniczenia zasady prawdy materialnej w procesie podnoszą więc argument $\mathrm{z}$ postępowań odrębnych jako rację uzasadniającą, iż zasada prawdy nie jest zasadą bezwzględnie obowiązującą - a więc może mieć co najwyżej status primus inter pares wśród innych zasad.

W tym momencie należy jednak odwołać się do doktryny procedury karnej, w której - przy istnieniu dogmatu prawdy obiektywnej - obowiązują liczne zakazy dowodowe, skutkujące możliwością nieodkrycia prawdy w procesie. Jak jednak trafnie pouczają Tomasz Grzegorczyk i Janusz Tylman w swym obszernym podręczniku, to nie zasada prawdy doznaje ograniczenia, lecz uszczuplone sa możliwości dokonania prawdziwych ustaleń faktycznych, przy aktualnym jej prymacie $\mathrm{w}$ procesie. ${ }^{33}$ Podobnie jest $\mathrm{w}$ cywilnych postępowaniach odrębnych - szczególnie tam, gdzie prawo przewiduje obecność prokuratora lub w grę wchodzi czynnik publicznoprawny. Dopuszczenie do zasądzenia sprzecznego z prawdą wyroku w szczególnych przypadkach w postępowaniach odrębnych jest wyrazem praktycznego stosowania słuszności, dbałości rozumnego ustawo-

\footnotetext{
${ }^{31}$ H. P i e t r z k o w s k i, Metodologia... op. cit., s. 25.

${ }^{32}$ Odrębny charakter „dogmatyczny” postępowań z zakresu praw stanu i stosunków między rodzicami a dziećmi ujawnia się również w utrzymaniu - pomimo tak dogłębnej i konsekwentnej nowelizacji kodeksu - inkwizycyjnych uprawnień sądu w tej materii np. w kwestii obowiązku przeprowadzenia przez sąd postępowania dowodowego, chociażby ograniczonego do zeznań stron w sprawie rozwodowej, nawet gdy strony zgodnie wnioskują o orzeczenie ustania ich małżeństwa.

${ }^{33}$ J. Ty $1 \mathrm{~m}$ a n, s. 77 [w:] T. Gr z e g o r c z y k, J. Ty $1 \mathrm{~m}$ a n, Polskie postępowanie karne, Warszawa 1998.
} 
dawcy o to, aby poznana rzeczywistość nie została uznana za wartość nadrzędną względem godności ludzkiej, nie zaś negowaniem potrzeby odkrycia przez sąd prawdy.

\section{Prawda jako podstawowa wartość $w$ procesie}

Wedle ulpianowskiej definicji prawo jest sztuką tego, co dobre i słuszne ${ }^{34}$, a właśnie dobrem nazywał Platon prawdę.

W ujęciu dynamicznym prawda to proces poznania, cel każdego postępowania sądowego, nie tylko karnego. Prawdy o stanie rzeczy rozpatrywanej na wokandzie dotyka się w każdym obiektywnym poznaniu, tkwi ona w samej istocie zasadnego orzekania. Tadeusz Ereciński stoi na stanowisku, że nakaz dążenia do prawdy przez sąd nie wymaga żadnego dogmatycznego uzasadnienia. ${ }^{35}$ Gdy jednak pewne rzeczy pierwsze nie zostają zapisane stają się postulatami, a nie dyrektywami. Tymczasem prawda nie może być postulatem lecz właśnie naczelną zasadą, ponieważ wyraża to, co najcenniejsze w procesie. Dlatego nie sposób zgodzić się z cytowanymi wcześniej poglądami suponującymi, że nic się nie stanie dla wymiaru sprawiedliwości, gdy w jakiejś sprawie cywilnej nie dojdzie się do prawdy. Wydanie takiego wyroku w procesie cywilnym, nawet jeśli chodzi o spór czysto prywatny będzie zawsze „przegraną” wymiaru sprawiedliwości, ponieważ osłabi przekonanie, ufność i wiarę konkretnej osoby bądź grupy osób, że sądy powszechne stoją na straży tego co prawdziwe, wzorcowe i obiektywne ${ }^{36}$.

Niepokojące są tendencje relatywistyczne, wątpiące ogólnie w możliwość dojścia do prawdy w procesie (prawdopodobieństwo zamiast prawdy). Jeżeli wspótczesny człowiek, ... nie w petni podziela a być może często $w$ ogóle nie podziela przekonania starożytnych, $\dot{z}$ e być jest lepiej niż nie być, że dobro jest lepsze od zła, a prawda lepsza od fatszu ... to zdarza się że problem prawdy sprowadzony zostaje do bardzo już dawno postawionego pytania: Prawda? Cóż to jest praw$d a ?(J 18,38)^{37}$. Każdy uczestnik postępowania sądowego musi mieć

\footnotetext{
${ }^{34}$ Ius est ars boni et aequi, Digesta, 1.1.1.

${ }^{35}$ T. E r e c i ń s k i, Wprowadzenie do Kodeksu postępowanie cywilnego, op. cit., s. 303.

${ }^{36}$ Strona zawsze będzie widzieć „swoją prawdę” - subiektywną ocenę rzeczywistości. To właśnie rolą sędziego jest dołożenie starań w każdej rozpatrywanej przez niego sprawie aby orzec sprawiedliwie, czyli zgodnie z rzeczywistym stanem rzeczy, a nie tylko tym podawanym jako taki przez strony.

${ }^{37}$ D. D e m b i ń s k a - S i u r y, Kilka uwag o wartości prawdy [w:] Wiedza a prawda,
} 
pewność, że prawda jest odkrywalna. To przekonanie nie powinno nigdy zachwiać sędzią. Poglądy bliskie stanowisku cyników wątpiących w prawdę dyskredytują możliwość wydania sprawiedliwego wyroku, co uderza w człowieka, a na dłuższą metę jest szkodliwe dla społeczeństwa i państwa.

Nie zamierzam nawoływać do powrotu do koncepcji pracy sądów sprzed 1996 r. Nie wydaje mi się jednak słuszne całkowite zrezygnowanie z przepisów mówiących o obowiązku wykrycia przez sąd prawdy w procesie. Przeciwko zmianom w artykule 3 k.p.c. oponował Senat ${ }^{38}$, wyrażenie „prawda obiektywna” rozumiana jako veritas rei jest również stosowane w doktrynie prawa kanonicznego ${ }^{39}$. Czy więc rzeczywiście znalezienie w kodeksie postępowania cywilnego miejsca dla wyrażonej wprost koncepcji prawdy byłoby wyrazem socjalistycznych zaszłości?

Marksistowska koncepcja prawa nie znała związków prawa ze sprawiedliwością, lecz podporządkowywała prawo rządom polityków. Nihilizm prawny stosowany w państwach socjalistycznych polegał jedynie na prawie stanowionym, odrzucając nawet elementy prawa natury i wartości takich jak: słuszność czy dobro. W swych założeniach filozoficznych socjalistyczny pozytywizm prawny zaprzeczał powiązaniom prawa z prawdą. Oderwanie racjonalności od moralności mogło służyć niegodziwym, niemoralnym i niesprawiedliwym ocenom ${ }^{40}$. Celem prawa materialnego miały być „obiektywne” normy, a celem postępowania „obiektywna” prawda, przy czym utożsamiano ten przymiotnik z „legalnością” postępowania i praworządnością (w rozumieniu „rządzenie przy pomocy prawa”). Nie o taki obiektywizm chodziło współczesnym przedstawicielom doktryny prawnej i demokratycznemu ustawodawcy, stąd nacisk na likwidację wyrażenia „prawda obiektywna w procesie”. Wydaje się jednak, że w wyniku chęci oderwania się od „socjalistycznych" zasad procesowych przysłowiowo wylano dziecko z kąpielą. Wyrażenie „prawda obiektywna”, chociaż powstało w konkretnej rzeczywistości politycznej, ewoluowało niezależnie od subiektyw-

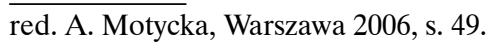

${ }^{38}$ Krótko o racjach Senatu: S. D a 1 k a, Zmiany w procedurze... op. cit., s. 29.

${ }^{39}$ R. S o b a ń s k i, Iudex veritatem de matrimonio dicit, Ius Matrimoniale 1999, nr. 4, s. 186.

${ }^{40} \mathrm{R}$. To k a r c z y k, Sprawiedliwość jako naczelna wartość prawa, Państwo i Prawo, 1997, nr. 6, s. 5. 
nego zamysłu ustawodawcy, a liczne przepisy powstałe pod rządami prymatu prawdy obiektywnej funkcjonowały dobrze przez wiele lat, służąc wartościom, które miały chronić ${ }^{41}$.

Czystość prawniczych konstrukcji, ich „eleganckość”, piękny język i spójność norm nie mogą być oderwane od wartości, którym prawo służy. Normy procesowe mają nie tylko „techniczny” charakter. Ich zadaniem jest urzeczywistnienie reguł postępowania zawartych w prawie materialnym. Współcześnie podkreśla się, że wyrok ma być legalnym, rzetelnym i racjonalnym działaniem sądu zmierzającym do określonych prawem celów, poprzez zastosowanie nakazanych reguł. Nie mniej ważnym jest dodanie, iż wyrok ma być rezultatem procesu poznania obiektywnej rzeczywistości, a nie tylko formą opanowania jej.

\section{Truth in the Light of novelized Polish Civil Law}

The article is a short review of the changes in Polish civil law procedure connected with the minimization of the „objective truth” principle.

The aim of the novelization was to accelerate the judges in their work, fulfil UE standards and regulations, and to activate the parties to responsible and diligence participation in the civil litigation.

The author generally agrees with the necessity of changes the procedural rules which have been set out by Polish Parliament, although in her critical point of view, judge's duty to adjudicate according with the objective truth - should never be inhibit.

${ }^{41}$ Przytaczam krytyczną argumentację T. Liszcz dotyczącą skreślenia $\$ 1$ art. $477^{1}$ zobowiązującego sąd pracy do prowadzenia $\mathrm{z}$ urzędu postępowania dowodowego o ustalenie istnienia stosunku pracy, gdy powód „nie udowodnił wszystkich faktów niezbędnych do takiego ustalenia": Pracodawca zwykle jest dobrze zabezpieczony w dokumentacji, często majacej niewiele wspólnego z rzeczywistością. Rzadko też pracownik może liczyć na zeznania kolegów, którzy boja się zeznawać prawdę w obawie przed utrata pracy. Sąd oczywiście także nie zawsze będzie w stanie uzyskać potrzebne do ustalenia prawdy dowody, jednakże jego obowiazkowa aktywność w tym zakresie jest bardzo ważna. Utrzymujące się wysokie bezrobocie zmusza wielu ludzi do tolerowania daleko idacych nadużyć pracodawców. W tych warunkach ostabianie pozycji procesowej pracownika $i$ zwalnianie sądu od obowiazku poszukiwania z urzędu prawdy materialnej jest szczególnie społecznie szkodliwe. [w:] Paragrafy eleganckie lecz bezduszne, „Rzeczpospolita” z 29 lipca 2008. (dostęp w wersji elektronicznej za pomocą serwisu internetowego http://new-arch. rp.pl/artykul/498514.html). 